\title{
Direct Versus Indirect Taxes: Impact on Economic Growth and Total Tax Revenue
}

\author{
Taufik Abd Hakim ${ }^{1}$ \\ ${ }^{1}$ Faculty of Business and Management, Universiti Teknologi MARA, Sabah, Malaysia \\ Correspondence: Taufik Abd Hakim, Faculty of Business and Management, Universiti Teknologi MARA, Sabah, \\ Malaysia. Tel: 6088-325-264.
}

Received: August 27, 2019

Accepted: December 2, 2019

Online Published: March 17, 2020

doi:10.5430/ijfr.v11n2p146

URL: https://doi.org/10.5430/ijfr.v11n2p146

\begin{abstract}
This study investigates the effects and consequences of both direct and indirect taxes on economic growth and total tax revenue in a panel of 51 countries over the period $1992-2016$. The data were estimated using the dynamic panel generalized method of moments (GMM) estimation. The results indicate that direct taxes are significant and negatively correlated with the economic growth, while indirect taxes seem to have a positive but insignificant impact on the dependent variable. Additionally, this study also found a significant and positive contribution of direct taxes on the total tax revenue compared to indirect taxes. The conclusion is that tax structure based on direct taxes such as taxes on income, profit and capital gains is harmful to the economic growth, yet more efficient in terms of collecting the tax revenue in a country.
\end{abstract}

Keywords: direct taxes, indirect taxes, economic growth, total tax revenue, dynamic panel GMM estimation

\section{Introduction}

Taxation is one of the most effective tools that serves to collect the necessary fund as revenue for public spending, improvement of infrastructure, as an economics' stabilizer and can influence the allocation of resources in a country (Prammer, 2011). The relevant literature has demonstrated the different impact of taxes on economic growth and other economic variables. According to Zipfel and Heinrichs (2012) that studied the impact of taxes on economic growth in European nations, taxes could alter the economic decisions where it can affect the economic growth negatively or positively. Ilaboya and Ohonba (2013) stressed that the different types of tax structures have different effect on macroeconomic indicators. In the system of taxation, there have commonly two types of taxes which are direct and indirect taxes. The tax revenue collected from indirect taxes such as goods and services taxes have contributed more than direct taxes such as personal income and corporate taxes (Masika, 2014).

The economics literature has witnessed many findings from the studies regarding the choice of direct and indirect taxes. The choice of direct and indirect taxes is important to determine the efficient of allocation resources especially tax revenue as well as improvement of economic growth. A study conducted by Lee and Gordon (2005) for 70 countries found the significant and negative relationship between statutory corporate tax rates and economic growth. The negative effects of corporate taxes on growth were supported by Schwellnus and Arnold (2008) and Vartia (2008). Their studies indicate a negative relationship between corporate taxes and productivity of firms which can be related to the economic growth across OECD countries. On the other hand, a study of taxes and economic growth by Ahmad et al. (2016) suggested to increase the direct taxes and cut the indirect taxes to stimulate the economic growth. Moreover, Widmalm (2001) revealed a negative relationship between income (direct) taxes and economic growth, while the negative effects of indirect taxes on economic growth are not confirmed.

However, a study conducted by Ecevit et al. (2016) found that both of direct and indirect taxes have positive effect on economic growth even in the long run where the impact of direct taxes is stronger compared to indirect taxes. In the case of Bulgaria, Tanchev (2016) revealed that the progressive income taxation especially taxes on personal income has positive impact on economic growth. The findings of these two studies were supported by Stoilova (2017) which mentioned that both taxes on personal income and consumption taxes have contributed in supporting the economic growth in European Union.

The main objective of this study is to investigate the impact of both direct and indirect taxes on economic growth for 
51 developing and developed countries, using dynamic panel two-step GMM estimation over the period 1992 - 2016. Besides that, this study also intends to reveal which type of tax structure, direct or indirect taxes are significant in optimizing the collection of tax revenue in a country.

This paper is organized as follows: Section 2 explains the methodology and data, Section 3 contains the empirical results and discussion for both direct and indirect taxes on economic growth and total tax revenue, and finally section 4 provides the conclusion of this study.

\section{Method and Data}

This study employs the two-step system GMM estimator proposed by Blundell and Bond (1998) to estimate the equations that based on the dynamic panel GMM estimators suggested by Arellano and Bond (1991).

\subsection{Dynamic Panel Two-Step System GMM Estimator}

According to a study conducted by Law et al. (2017), the two-step system GMM estimator is one of the best estimators in the dynamic panel data analysis due to unbiased and consistent in parameter estimates compared to the difference GMM estimator. Furthermore, the two-step system GMM estimator is much more efficient in dealing with the problem of endogeneity compared to the fixed effects and difference GMM models.

However, Windmeijer (2005) and Browsher (2002) reveals that the two-step system GMM estimator lead to produce biased standard errors and a weakened over-identification (Sargan) test for the case of small sample analysis. In order to overcome these problems, Windmeijer (2005) produces the Windmeijer (WC) robust standard errors for the two-step system GMM estimator. Additionally, a study of instruments in the model estimation by Roodman (2009) showed the problem of too many instruments occurs when a study uses small sample analysis. This situation makes the two-step system GMM tend to be biased and not an accurate estimator. In order to avoid dealing with too many instruments, the researchers have to make sure the number of samples is large and small period of time. One of the innovative solutions to overcome this problem is by averaging the period of time which believed can avoid the problem of too many instruments (Law et al., 2017; Roodman, 2009).

There have two important tests need to be conducted in the two-step system GMM estimator, namely, the Sargan test of over-identifying restrictions and an autocorrelation test in the disturbance proposed by Arellano and Bond (1991). In this case, the null hypothesis of the Sargan test that mention overidentifying restrictions are valid cannot be rejected to make sure the model is correctly specified, and instruments use are valid. For the autocorrelation test, the second-order autocorrelation (AR2) should not be rejected in all cases. In this study, the standard errors of two-step GMM estimator were adjusted by using the Windmeijer (WC) robust standard errors.

\subsection{Empirical Model}

The purpose of this study is to investigate the effect of tax structures on economic growth and the collection of tax revenue. This study considers the GDP growth and total tax revenue as dependent variables, while both of direct and indirect taxes are independent variables. The direct taxes consist of taxes on income, profits and capital gains, while taxes on goods and services is included as an indirect tax. The basic function of this study can be written as follow:

$$
y_{i t}=\alpha+\beta_{0} \lambda_{i t}+\beta_{1} \chi_{i t}+\varepsilon_{i t}
$$

where $y$ is dependent variables (GDP growth and total tax revenue), $\alpha$ is intercept, $\beta_{0}$ and $\beta_{1}$ are the slops of direct and indirect taxes, $\varepsilon_{i t}$ is the error term, $i$ is the country and $t$ is the time.

The empirical model of this study is based on studies conducted by Tosun (2005), Arisoy and Unlukaplan (2010) and Petru-Ovidiu (2015) which studied the effect of tax structures and other economic indicators on economic growth and total tax revenue. The model regression of this study also includes the control variables derived from the appropriate growth literature which consist of economic indicators. However, this study adopts the dynamic panel data analysis to relate the explanatory variables and dependent variables. The empirical version of equation (1) is specified as follows:

$y_{i t}=\alpha G D P_{i t-1}+\beta_{1} D T_{i t}+\beta_{2} I D T_{i t}+\beta_{3} G P P_{i t}+\beta_{4} F I X_{i t}+\beta_{5} F D I_{i t}+\beta_{6} I N F_{i t}+\beta_{7} T R A D_{i t}+\beta_{8} U N E P_{i t}+\eta_{i}+\varepsilon_{i t}$

where $y$ is the growth rate of GDP and total tax revenue/GDP, DT is direct taxes (taxes on income, profit and capital gains/revenue) and IDT is indirect taxes (taxes on goods and services/revenue). The set of control variables are selected based on several important economic indicators that can affect economic growth as in a country. The control variables are GDP per capita growth $(G P P)$, gross fixed capital formation/GDP $(F I X)$, foreign direct investment/GDP $(F D I)$, inflation $(I N F)$, trade openness/GDP $(T R A D)$ and unemployment (UNEP). GDP per capita growth is measured by annual percentage growth rate of GDP per capita based on constant local currency. Gross fixed capital formation 
is measured based on the net increase in physical assets (exclude disposals) as percentage of GDP. The other control variable is foreign direct investment which includes the net inflow of investment from foreign investors divided by GDP. Inflation shows the rate of price change in the economy as a whole, while trade openness is the sum of exports and imports of goods and services as percentage of GDP. The last control variable is unemployment that refers to the percentage of total labor force in a country. $\eta_{i}$ is the unobserved country-specific effect term, $\varepsilon_{i t}$ is the error term, $i$ is the country and $t$ is the time.

However, Arisoy and Unlukaplan (2010) mentions that the collinearity problem between direct and indirect taxes might occur in equation (2). Having this in mind, this study estimate equation (2) for both direct and indirect taxes separately, as follows:

$$
\begin{gathered}
y_{i t}=\alpha G D P_{i t-1}+\beta_{1} D T_{i t}+\beta_{2} G P P_{i t}+\beta_{3} F I X_{i t}+\beta_{4} F D I_{i t}+\beta_{5} I N F_{i t}+\beta_{6} T R A D_{i t}+\beta_{7} U N E P_{i t}+\eta_{i}+\varepsilon_{i t} \\
y_{i t}=\alpha G D P_{i t-1}+\beta_{1} I D T_{i t}+\beta_{2} G P P_{i t}+\beta_{3} F I X_{i t}+\beta_{4} F D I_{i t}+\beta_{5} I N F_{i t}+\beta_{6} T R A D_{i t}+\beta_{7} U N E P_{i t}+\eta_{i}+\varepsilon_{i t}
\end{gathered}
$$

Additionally, in order to confirm the model regressions would not suffer from collinearity problem, the Variance Inflation Factor (VIF) test is conducted. The value of VIF should be less than 10 to confirm that the collinearity problem among explanatory variables is not exist (Hair et al., 1995). Moreover, this study also includes the correlation matrix to support the results generated by VIF test. According to Field (2005), the problem of multicollinearity is existing if the correlation coefficients between two variables exceeds 0.80 .

\subsection{Data}

To estimate the models, this study employs panel data of 51 countries from developing and developed countries over the period 1992 - 2016 (see Appendix 1). The datasets were collected from World Development Indicators (WDI), World Bank. In order to avoid the problem of too many instruments mentioned by Roodman (2009), the period of time was averaged into five-year intervals which consists of $1992-1996,1997-2001,2002-2006,2007-2011$ and 2012 - 2016 (Law et al., 2017). Besides, the GMM estimator required a large sample $(n)$ with a small number of time period $(t)$ where this study includes 51 countries with five-year intervals.

Table 1. Descriptive statistics N $=51$ cross-country. $T=1992-2016$

\begin{tabular}{llllll}
\hline Variable & Unit of Measurement & Mean & Std Dev & Min & Max \\
\hline GDP & US $\$ 2010$ constant Price & 3.26 & 2.34 & -7.3 & 9.56 \\
\hline GPP & US $\$ 2010$ constant Price & 2.31 & 2.18 & -7.23 & 9.31 \\
\hline DT & \% of revenue & 27.56 & 12.15 & 2.98 & 65.97 \\
\hline IDT & \% of revenue & 32.89 & 9.98 & 2.73 & 62.78 \\
\hline TAX & \% of GDP & 18.73 & 6.91 & 7.71 & 56.00 \\
\hline INF & Percent & 15.34 & 91.33 & -1.22 & 1076.38 \\
\hline UNEP & Percent & 7.40 & 4.60 & 0.60 & 25.83 \\
\hline FDI & \% of GDP & 6.28 & 16.59 & -1.63 & 168.12 \\
\hline FIX & \% of GDP & 22.67 & 4.63 & 11.23 & 40.37 \\
\hline TRAD & \% of GDP & 92.99 & 66.00 & 16.97 & 399.33 \\
\hline
\end{tabular}

Table 1 shows the descriptive statistics for the data used in this study. Based on the table, the contribution of tax revenue can be shown by the mean value of tax revenue collected which reported $18.73 \%$ of GDP. The highest contributor of the collection of tax revenue (56\% of GDP) among 51 countries selected was stated by Malta, while the lowest collection of tax revenue (7.71\% of GDP) was recorded by Guatemala. Both of direct and indirect taxes has contributed more than $50 \%$ of revenue which indicates that these taxes are important as the main sources of revenue for a country. By looking at these two types of taxes, this study found that taxes on goods and services that classified as indirect taxes has an average value of $32.89 \%$ of revenue which is slightly higher than taxes on income profits and capital gains (27.56\% of revenue). Among all the variables, the value of standard deviations for inflation was widely spread around the mean. This is due to the unfavorable economic conditions especially fluctuation in the prices of oil and gas that significantly affect the cost of production as well as price of final goods and services. 
Table 2. Correlations

\begin{tabular}{|c|c|c|c|c|c|c|c|c|c|c|}
\hline & GDP & GPP & FIX & FDI & INF & TRAD & UNEP & DT & IDT & TAX \\
\hline GDP & 1.0000 & & & & & & & & & \\
\hline GPP & 0.7881 & 1.0000 & & & & & & & & \\
\hline FIX & 0.2474 & 0.4015 & 1.0000 & & & & & & & \\
\hline FDI & 0.0056 & -0.0227 & -0.0558 & 1.0000 & & & & & & \\
\hline INF & 0.0004 & -0.0052 & -0.0697 & -0.0363 & 1.0000 & & & & & \\
\hline TRAD & 0.1672 & 0.1331 & 0.1659 & 0.4948 & -0.0897 & 1.0000 & & & & \\
\hline UNEP & -0.1198 & -0.0654 & -0.3101 & -0.0567 & 0.0031 & -0.1763 & 1.0000 & & & \\
\hline DT & -0.0442 & -0.1174 & 0.0881 & 0.0210 & -0.1020 & -0.0329 & 0.0288 & 1.0000 & & \\
\hline IDT & 0.1497 & 0.2131 & -0.1187 & -0.0018 & -0.0521 & -0.0971 & 0.1296 & -0.3199 & 1.0000 & \\
\hline TAX & -0.0800 & -0.0504 & -0.1250 & 0.4083 & -0.0888 & 0.2873 & 0.0879 & 0.1031 & 0.0174 & 1.0000 \\
\hline
\end{tabular}

Table 2 presents the correlation matrix among all the variables. The main purpose of the correlation matrix is to indicate the linear relationship between all variables. This study found a mixed result regarding the linear relationship between both of taxes and GDP growth. The correlation matrix reveals that direct taxes has a negative correlation with GDP growth, while indirect taxes has a positive correlation with GDP growth. Even though the correlation matrix shows a mixed result, yet both direct and indirect taxes are negatively correlated with most of variables. Regarding the collecting of tax revenue, these taxes still contributed and positively related to tax revenue. Furthermore, the correlation coefficients show a value between 0.0004 to 0.7881 indicate that all variables are free from the problem of multicollinearity.

\section{Results and Discussion}

The regression results of equations (2), (3) and (4) using dynamic panel two-step GMM are presented in the Table 3. The result of Sargan test shows the over identifying restrictions are valid and not rejected, while the result of Arellano-Bond test shows the absence of second-order serial correlation. These results indicate that the model is well specified and the method of dynamic panel GMM is an appropriate estimation. The main interest of this study is to investigate the impact of direct and indirect taxes on economic growth. First model includes both direct and indirect taxes, second model without indirect taxes and third model includes direct taxes only. The results of direct taxes show statistically significant at 5\% and 10\% levels and negatively correlated with economic growth for both model 1 and model 2. This implies that 10 percentage points increase in direct taxes leads to decrease in the GDP growth by between 0.190 and 0.201 percentage points.

However, for the case of indirect taxes, the results from model 1 and model 3 reveal that indirect tax has a positive but not significant on the economic growth. These findings are in line with studies conducted by Widmalm (2001), Schwellnus and Arnold (2008), Vartia (2008), Johansson et al. (2008), Acosta- Ormaechea and Yoo (2012) and Petru-Ovidiu (2015) who argue that direct taxes have burdened the economic growth, while indirect taxes have positive relationship with economic growth but not significant. Moreover, a study conducted by Arnold (2008) concludes that direct taxes such as corporate income taxes are the most harmful to economic growth, while indirect taxes such as consumption and property taxes are less harmful to economic growth. When looking at the control variables, three of the control variables which are GDP per capita growth, gross fixed capital formation and inflation have statistically significant, being positively, respectively negatively related to economic growth.

Table 4 presents the relationship between these two types of taxes and the collection of total tax revenue. The results of the two diagnostic tests are satisfactory where the Sargan test and AR(2) are not rejected. Based on model 1 and model 2, the empirical results reveal that direct taxes has a positive and significant contribution on total tax revenue. These results are supported by a recent study conducted by Sorsa and Durga Rao (2018) which mentioned direct tax is one of the significant sources of revenue in a country. 
Table 3. Results of dynamic panel GMM estimations (dependent variable: GDP growth)

\begin{tabular}{|c|c|c|c|}
\hline Variables & Model 1 & Model 2 & Model 3 \\
\hline \multirow[t]{2}{*}{$\mathrm{GDP}_{\mathrm{it}-1}$} & 0.0122 & 0.01782 & 0.0622 \\
\hline & $(0.0679)$ & $(0.0668)$ & $(0.0697)$ \\
\hline \multirow[t]{2}{*}{$\mathrm{DT}_{\mathrm{it}}$} & $-0.0190 * *$ & $-0.0201 *$ & - \\
\hline & $(0.0097)$ & $(0.0109)$ & \\
\hline \multirow[t]{2}{*}{$\mathrm{IDT}_{\mathrm{it}}$} & 0.0039 & - & 0.0045 \\
\hline & $(0.0064)$ & & $(0.0066)$ \\
\hline \multirow[t]{2}{*}{$\mathrm{GPP}_{\text {it }}$} & $0.3448 * * *$ & $0.3499 * * *$ & $0.3429 * * *$ \\
\hline & $(0.0288)$ & $(0.0297)$ & $(0.0297)$ \\
\hline \multirow[t]{2}{*}{ FIX $_{\text {it }}$} & $0.0240 * *$ & $0.0246 * *$ & 0.0181 \\
\hline & $(0.0096)$ & $(0.0102)$ & $(0.0115)$ \\
\hline \multirow[t]{2}{*}{$\mathrm{FDI}_{\mathrm{it}}$} & 0.0006 & 0.0007 & 0.0002 \\
\hline & $(0.0006)$ & $(0.0006)$ & $(0.0005)$ \\
\hline \multirow[t]{2}{*}{$\mathrm{INF}_{\mathrm{it}}$} & $-0.0271 * * *$ & $-0.0270 * * *$ & $-0.0300 * * *$ \\
\hline & $(0.0062)$ & $(0.0062)$ & $(0.0063)$ \\
\hline \multirow[t]{2}{*}{ TRAD $_{\text {it }}$} & 0.0003 & 0.0006 & -0.0004 \\
\hline & $(0.0020)$ & $(0.0021)$ & $(0.0020)$ \\
\hline \multirow[t]{2}{*}{$\mathrm{UNEP}_{\mathrm{it}}$} & -0.0097 & -0.0094 & -0.0024 \\
\hline & $(0.0207)$ & $(0.0220)$ & $(0.0191)$ \\
\hline \multirow[t]{2}{*}{ Constant } & 0.2087 & 0.2942 & -0.2400 \\
\hline & $(0.3857)$ & $(0.3798)$ & $(0.3710)$ \\
\hline \multirow[t]{2}{*}{ Sargan test } & 6.74 & 7.65 & 6.55 \\
\hline & {$[0.5650]$} & [0.4683] & {$[0.5863]$} \\
\hline \multirow[t]{2}{*}{ A.Bond test $\mathrm{AR}(2)$} & 0.72 & 0.74 & 0.70 \\
\hline & {$[0.4698]$} & {$[0.4576]$} & {$[0.4853]$} \\
\hline VIF & 1.27 & 1.25 & 1.27 \\
\hline No. of instruments & 18 & 17 & 17 \\
\hline No. of country & 51 & 51 & 51 \\
\hline No. of observations & 204 & 204 & 204 \\
\hline
\end{tabular}

Notes: Values in the parentheses () and [] are Windmeijer (WC) robust standard errors and p-values. ***, **, * indicate statistical significance at the $1 \%, 5 \%$ and $10 \%$ levels, respectively.

However, the results generated from model 1 and model 3 shows insignificant relationship between indirect taxes and total tax revenue. This finding can be supported by a study done by Emran and Stiglitz (2005) which mentioned the inefficiency of indirect taxes (VAT) in terms of collecting the tax revenue was due to the presence of a large informal economy (non-taxable sectors) especially in developing countries. The average share of informal economy was $14.5 \%$ of GDP in developing countries, while 35\% of GDP in developed countries (Bolton and Dollery, 2004). Furthermore, Di John (2006) also recommended the countries to diversify the revenue from indirect taxes (regressive taxes) to progressive income tax and property tax in the long run.

Table 4. Results of dynamic panel GMM estimations (dependent variable: Total tax revenue)

\begin{tabular}{llll}
\hline Variables & Model 1 & Model 2 & Model 3 \\
\hline TAX $_{\mathrm{it}-1}$ & $0.7324 * * *$ & $0.7204 * * *$ & $0.7327^{* * *}$ \\
& $(0.1529)$ & $(0.1681)$ & $(0.1220)$ \\
\hline
\end{tabular}




\begin{tabular}{|c|c|c|c|}
\hline$\overline{\mathrm{DT}_{\text {it }}}$ & $\begin{array}{l}0.1305^{* *} \\
(0.0647)\end{array}$ & $\begin{array}{l}0.1417 * * \\
(0.0560)\end{array}$ & - \\
\hline $\mathrm{IDT}_{\text {it }}$ & $\begin{array}{l}-0.0228 \\
(0.0679)\end{array}$ & - & $\begin{array}{l}-0.0467 \\
(0.0540)\end{array}$ \\
\hline $\mathrm{GPP}_{\text {it }}$ & $\begin{array}{l}\text { 0.2137* } \\
(0.1102)\end{array}$ & $\begin{array}{l}0.2042 * \\
(0.1107)\end{array}$ & $\begin{array}{l}0.2179 * * \\
(0.0949)\end{array}$ \\
\hline FIX $_{\text {it }}$ & $\begin{array}{l}0.0002 \\
(0.0495)\end{array}$ & $\begin{array}{l}0.0034 \\
(0.0517)\end{array}$ & $\begin{array}{l}0.0291 \\
(0.0528)\end{array}$ \\
\hline $\mathrm{FDI}_{\mathrm{it}}$ & $\begin{array}{l}-0.0015 \\
(0.110)\end{array}$ & $\begin{array}{l}-0.0022 \\
(0.0121)\end{array}$ & $\begin{array}{l}0.0011 \\
(0.0098)\end{array}$ \\
\hline $\mathrm{INF}_{\text {it }}$ & $\begin{array}{l}-0.0218 * * * \\
(0.0055)\end{array}$ & $\begin{array}{l}-0.0212 * * * \\
(0.0055)\end{array}$ & $\begin{array}{l}-0.0182 * * * \\
(0.0055)\end{array}$ \\
\hline TRAD $_{\text {it }}$ & $\begin{array}{l}-0.0481 * * * \\
(0.1111)\end{array}$ & $\begin{array}{l}-0.0482 * * * \\
(0.0123)\end{array}$ & $\begin{array}{l}-0.0422 * * * \\
(0.0086)\end{array}$ \\
\hline$\overline{\mathrm{UNEP}_{\text {it }}}$ & $\begin{array}{l}0.1703^{*} \\
(0.0906)\end{array}$ & $\begin{array}{l}0.1780^{*} \\
(0.0992)\end{array}$ & $\begin{array}{l}0.1584^{*} \\
(0.0860)\end{array}$ \\
\hline Constant & $\begin{array}{l}4.7406 \\
(4.3836)\end{array}$ & $\begin{array}{l}3.7243 \\
(3.3346)\end{array}$ & $\begin{array}{l}8.0830 * * \\
(3.4200)\end{array}$ \\
\hline Sargan test & $\begin{array}{l}10.27 \\
{[0.2463]}\end{array}$ & $\begin{array}{l}10.52 \\
{[0.2304]}\end{array}$ & $\begin{array}{l}7.99 \\
{[0.4348]}\end{array}$ \\
\hline A.Bond test $\mathrm{AR}(2)$ & $\begin{array}{l}0.04 \\
{[0.9687]} \\
1.27\end{array}$ & $\begin{array}{l}0.03 \\
{[0.9738]} \\
1.27\end{array}$ & $\begin{array}{l}0.28 \\
{[0.9898]} \\
1.25\end{array}$ \\
\hline No. of instruments & 18 & 17 & 17 \\
\hline No. of country & 51 & 51 & 51 \\
\hline No. of observations & 204 & 204 & 204 \\
\hline
\end{tabular}

Notes: Values in the parentheses () and [] are Windmeijer (WC) robust standard errors and p-values. ***, **, * indicate statistical significance at the $1 \%, 5 \%$ and $10 \%$ levels, respectively.

In this case, the implementation of indirect taxes such as taxes on goods and services can be considered inefficient to maximize the collection of tax revenue due to high percentage of informal sectors which not included as a part of tax revenue in a country. The issue of insignificant relationship between indirect taxes and total tax revenue can be related with a model proposed by Ramsey (1927) known as the Ramsey optimum tax rule. According to his study, all goods should be taxed at different rates and concludes that the introduction of consumption tax in the tax system would reduce the demand for each good at the same percentage. It indicates that the introduction of consumption tax (indirect taxes) can be considered not significant to increase the tax revenue due to fall in demand of goods. Additionally, the Lerner and Dixit models created by Lerner (1970) and Dixit (1970) mentions that, if taxes on certain goods are increased, people tend to shift their consumption from taxable good sector to the untaxed sector, and vice versa. Thus, people have their option to shift their consumption from taxable to non-taxable sectors (informal economy) where the government unable to maximize the collection of tax revenue from this kind of taxes.

\section{Conclusion}

The main objective of this study is to examine the effect of both direct and indirect taxes on the economic growth and the collection of tax revenue in 51 developing and developed countries. The findings suggest that direct taxes have a negative and significant effect on economic growth, while indirect taxes show positive but insignificant relationship with economic growth. Additionally, this study found a mixed result regarding the significant contribution of both direct and indirect taxes on the collection of tax revenue in a country. It indicates that indirect taxes such as consumption tax and taxes on goods and services are seems not significant and inefficient in 
maximizing the collection of tax revenue due to the existence of a large informal economy which can be related to the non-taxable sectors especially in developing countries. In this case, the government might unable to maximize the collection of tax revenue from indirect taxes compared to direct taxes such as taxes on personal income, profits and capital gains.

\section{References}

Acosta-Ormaechea, S., \& Yoo, Y. (2012). Tax Composition And Growth: A Broad Cross-Country Perspective. IMF Working Paper 257. https://doi.org/10.5089/9781616355678.001

Ahmad, S., Sial, M. H., \& Ahmad, N. (2016). Taxes and Economic Growth: An Empirical Analysis of Pakistan. European Journal of Business And Social Sciences, 5(2), 16-29. https://doi.org/10.21859/eulawrev-08062

Arellano, M., \& Bond S. (1991). Some Tests of Specification for Panel Data: Monte Carlo Evidence and An Application to Employment Equations. Review of Economic Studies, 58(2), 277-297. https://doi.org/10.2307/2297968

Arisoy, I., \& Unlukaplan, I. (2010). Tax Composition and Growth in Turkey. International Research Journal of Finance and Economics, 59, 50-61.

Arnold, J. (2008). Do Tax Structure Affect Aggregate Economic Growth? Empirical Evidence From a Panel of OECD Countries. OECD Economics Department Working Paper 643. OECD Paris.

Blundell, R., \& Bond, S. (1998). Initial Conditions and Moment Restrictions in Dynamic Panel Data Models. Journal of Econometrics, 87(1), 115-143. https://doi.org/10.1016/S0304-4076(98)00009-8

Bolton, T., \& Dollery, B. (2004). Effects of the GST in Australia, Canada and New Zealand. Working Paper Series in Economics 17, University of New England School of Economics.

Bowsher, C. (2002). On Testing Overidentifying Restrictions in Dynamic Panel Data Models. Economic Letter, 77(2), 211-220. https://doi.org/10.1016/S0165-1765(02)00130-1

Di John, J. (2006). The Political Economy of Taxation and Tax Reform in Developing Countries. Research Paper 2006/074. Helsinki: UNU-WIDER.

Dixit, A. K. (1970). On the Optimum Structure of Commodity Taxes. The American Economic Review, 60(3), 295-310.

Ecevit, E., \& Yucel, A. G. (2016). Are Some Taxes Better Than Others for Economic Growth? An ARDL Approach of Turkey. The Empirical Economics Letters, 15(11), 1129-1136.

Emran, S. M., \& Stiglitz, J. E. (2005). On selective indirect tax reform in developing countries. Journal of Public Economics, 89, 599-623. https://doi.org/10.1016/j.jpubeco.2004.04.007

Field, A. (2005). Discovering Statistics Using SPSS. London: Sage Publication Ltd.

Hair, J. F., Anderson, R. E. Jr., Tatham, R. L., \& Black, W. C. (1995). Multivariate Data Analysis (3rd ed.). New York: Macmilan Publishing Company.

Ilaboya, O. J., \& Ohonda, N. (2013). Direct versus Indirect Taxation and Income Inequality. European Journal of Accounting \& Finance Research, 1(1), 1-15.

Johansson, A., Heady, C., Arnold, J., Brys, B., \& Vartia, L. (2008). Taxation and Economic Growth. OECD Economics Department Working Papers 620.

Law, S. H., Kutan, A. M., \& Naseem, N. A. M. (2017). The Role of Institutions in Finance Curse: Evidence from International Data. Journal of Comparative Economics, 46(1), 174-191. https://doi.org/10.1016/j.jce.2017.04.001

Lee, Y., \& Gordon, R. H. (2005). Tax Structure and Economic Growth. Journal of Public Economics, 89(5-6), 1027-1043. https://doi:10.1016/j.jpubeco.2004.07.002

Lerner, A. P. (1970). On Optimal Taxes With An Untaxable Sector. American Economic Review, 60(3), 284-294.

Masika, J. N. (2014). Direct Taxes and Economic Growth in Kenya. Nairobi, Kenya: University Of Nairobi.

Petru-Ovidiu, M. (2015). Tax Composition and Economic Growth: A Panel-Model Approach for Eastern Europe. Annals of the Constantin Brancusi University of Targu Jiu, Economy Series, 1(2), 89-101.

Prammer, D. (2011). Quality of Taxation and the Crisis: Tax Shifts from A Growth Perspective. Taxation Papers 29. Directorate General Taxation and Customs Union: European Commission. 
Ramsey, F. P. (1927). A Contribution to the Theory Of Taxation. The Economic Journal, 37, 47-61. http://dx.doi.org/10.2307/2222721

Roodman, D. (2009). A Note on the Theme of Too Many Instruments. Oxford Bulletin Economic Statitics, 71(1), 135-158. https://doi.org/10.1111/j.1468-0084.2008.00542.x

Schwellnus, C., \& Arnold, J. (2008). Do Corporate Taxes Reduce Productivity and Investment at the Firm Level? Cross-Country Evidence from the Amadeus Dataset. OECD Economics Department Working Papers 641. OECD Publishing.

Sorsa, B., \& Durga Rao, P. (2018). Analysis of the Contribution of Tax to the Local Government Revenue Generation. International Journal of Business and Management Invention, 7(4), 47-56.

Stoilove, D. (2017). Tax Structure and Economic Growth: Evidence from the European Union. Accounting and Management, 62(3),1041-1057. https://doi.org/10.1016/j.cya.2017.04.006

Tanchev, S. (2016). The Role of the Proportional Income Tax on Economic Growth of Bulgaria. Economic Studies Journal, 25(4), 66-77.

Tosun, M. S. (2005). The Tax Structure and Trade Liberalization of the Middle East and North Africa Region. Review of Middle East Economics and Finance, 3(1), 21-38. https://doi.org/10.1080/14753680500063952

Vartia, L. (2008). How do Taxes Affect Investment and Productivity? Industry Level Analysis of OECD Countries. OECD Economic Working Papers 656.

Widmal, F. (2001). Tax Structure and Growth: Are Some Taxes Better Than Others? Public Choice, 107(3-4), 199-219. https://doi.org/10.1023/A:1010340017288

Windmeijer, F. (2005). A Finite Sample Correction for the Variance of Linear Efficient Two Step GMM Estimators. Journal of Econometrics, 126(1), 25-51. https://doi.org/10.1016/j.jeconom.2004.02.005

Zipfel, F., \& Heinrichs, C. (2012). The Impact of Tax Systems on Economic Growth in Europe: An Overview. Deutsche Bank Research.

\section{Appendix}

Appendix 1. List of countries

\begin{tabular}{llllll}
\hline No. & Country & No. & Country & No & Country \\
\hline 1 & Australia & 18 & Hungary & 35 & Peru \\
2 & Austria & 19 & Iceland & 36 & Philippines \\
3 & Belarus & 20 & India & 37 & Poland \\
4 & Belgium & 21 & Indonesia & 38 & Portugal \\
5 & Belize & 22 & Ireland & 39 & Romania \\
6 & Brazil & 23 & Italy & 40 & Singapore \\
7 & Bulgaria & 24 & Japan & 41 & Slovak Rep. \\
8 & Chile & 25 & Kenya & 42 & South Africa \\
9 & Cyprus & 26 & Korea Rep. & 43 & Spain \\
10 & Czech Rep. & 27 & Madagascar & 44 & Sri Lanka \\
11 & Denmark & 28 & Luxembourg & 45 & Sweden \\
12 & Dominican Rep. & 29 & Malaysia & 46 & Switzerland \\
13 & Finland & 30 & Malta & 47 & Thailand \\
14 & France & 31 & Mauritius & 48 & United Kingdom \\
15 & Germany & 32 & Nepal & 49 & United States \\
16 & Greece & 33 & Netherland & 50 & Uruguay \\
17 & Guatemala & 34 & Norway & 51 & Vietnam \\
\hline
\end{tabular}

